Review

\title{
Potential Antiviral Agents from Marine Fungi: An Overview
}

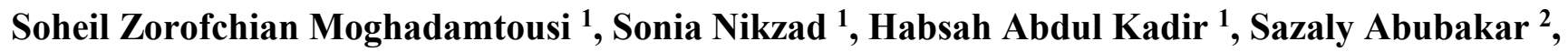 and Keivan Zandi ${ }^{2,3, *}$}

1 Biochemistry Program, Institute of Biological Sciences, Faculty of Science, University of Malaya, 50603 Kuala Lumpur, Malaysia; E-Mails: soheil.zorofchian@gmail.com (S.Z.M.); sonia.nikzad@gmail.com (S.N.); habsah@um.edu.my (H.A.K.)

2 Department of Medical Microbiology, Tropical Infectious Disease Research and Education Center (TIDREC), Faculty of Medicine, University of Malaya, 50603 Kuala Lumpur, Malaysia;

E-Mail: sazaly@um.edu.my

3 The Persian Gulf Marine Biotechnology Research Center, Bushehr University of Medical Sciences, Bushehr 75169, Iran

* Author to whom correspondence should be addressed; E-Mail: keivan@um.edu.my; Tel./Fax: +603-796-766-74.

Academic Editor: Johannes F. Imhoff

Received: 3 June 2015 / Accepted: 15 June 2015 / Published: 22 July 2015

\begin{abstract}
Biodiversity of the marine world is only partially subjected to detailed scientific scrutiny in comparison to terrestrial life. Life in the marine world depends heavily on marine fungi scavenging the oceans of lifeless plants and animals and entering them into the nutrient cycle by. Approximately 150 to 200 new compounds, including alkaloids, sesquiterpenes, polyketides, and aromatic compounds, are identified from marine fungi annually. In recent years, numerous investigations demonstrated the tremendous potential of marine fungi as a promising source to develop new antivirals against different important viruses, including herpes simplex viruses, the human immunodeficiency virus, and the influenza virus. Various genera of marine fungi such as Aspergillus, Penicillium, Cladosporium, and Fusarium were subjected to compound isolation and antiviral studies, which led to an illustration of the strong antiviral activity of a variety of marine fungi-derived compounds. The present review strives to summarize all available knowledge on active compounds isolated from marine fungi with antiviral activity.
\end{abstract}

Keywords: natural products; marine fungi; antiviral; review 


\section{Introduction}

The marine world contains approximately one half of all species [1,2]. The vast expanse of the ocean and its unique environment are responsible for the exceptional chemical and biological diversity of marine organisms, with 300,000 described species and far more still to investigate [3]. The fact that less than $0.01 \%-0.1 \%$ of microbial species from the ocean are known to scientists highlights how effectively marine exploration can open up numerous avenues to marine organisms and their active chemical constituents [4]. Virtually all types of marine organisms, including algae, ascidians, bacteria, corals, fungi, and sponges, have come under scientific scrutiny for their natural products $[5,6]$. As a result of these studies, the ocean provides agrichemicals, cosmetics, enzymes, nutritional supplements, and pharmaceuticals, with great commercial prospects [7-9].

Historically, the pivotal role of fungi in different aspects of human life is very pronounced and this is true even in the marine world [10]. Marine fungi belong to the phyla Ascomycota, Bacidomycota, Chytridiomycota, Deuteromycota, and Zygomycota [11]. Evolution of these heterotrophic eukaryotes to degrade different solid substrates helps them to recycle dead plants (e.g., lignan and cellulose) and animal tissues (e.g., chitin and keratin) into the marine ecosystem through decomposition [10,12]. Investigations on marine fungi primarily commenced because of certain infections in the marine environment. Tolerance of some terrestrial species to the conditions of the marine ecosystem, including salt concentration, has made them potent pathogens in the marine world [13]. For instance, pathogenicity of genus Aspergilus and Fusarium solani contributed to the mortality of the Caribbean sea-fan and the infections of different marine crustaceans, respectively [14,15]. In addition, blue crabs, lobster eggs, and cultured crabs were reported to be infected by Lagenidium callinectes [16].

Despite the pathogenicity of certain marine fungi species, mutualistic interactions are the dominant types of relationship found in marine fungi [12]. The life of marine fungi heavily depends on their symbiotic relationships with other marine organisms such as algae and marine invertebrates [17]. For instance, Turgidosculum ulvae can only be grown in the thallus of Blidingia minima, a green algae [18]. Moreover, different Penicillium and Aspergillus species in the marine environment are isolated from sponges [19]. Isolation of these species requires the collection of the supporting material or host marine organism. Therefore, investigations on marine fungi confront the serious impediment of preserving samples until extraction [17].

As scientific interest has been sparked in marine microorganisms, fungi and their metabolites have begun to be recognized for their potent biological activities in the past few decades. Some of these metabolites give marine fungi the superiority to adapt to extreme habitats, compete for substrates, and ward off threats [20]. Moreover, fungi metabolites may be affected by their source of isolation, including sponges or other invertebrates, whose tissues they are harboring on or living in. Compounds isolated from marine fungi elicited promising assorted biological activities, especially anticancer and antidiabetic properties. However, other pharmaceutical activities have also reported, including cell cycle inhibition, kinase and phosphatase inhibition, antioxidant, neuritogenic, anti-inflammatory, antiplasmodial, and antiviral activities [12,21-24]. 


\section{Marine Fungi and Their Antiviral Activity}

Viruses encompass a prodigious group of microorganisms causing assorted infectious diseases. Recent scientific studies triumphantly reported new antiviral agents, which generally inhibit the virus replication cycle through affecting the important host cell factor(s) for virus replication and/or viral elements [25]. Despite the marked development in antiviral pharmaceuticals over the past few decades, patients suffering from viral infections are severely afflicted with treatment failure mostly because of the emergence of recombinant viruses, drug resistance, and cell toxicity [26-28]. Moreover, the widespread occurrence of chronic viral infectious diseases, including human immunodeficiency virus (HIV) and viral hepatitis, clearly warrants exploration of new therapeutic agents with higher efficiency and diminished side effects. From 1981 to 2010, only 18 out of 110 established antiviral drugs were biological derivatives of natural products, including laninamivir, oseltamivir, and zanamivir. Nonetheless, the portion of synthetic drugs made of modified nucleosides and peptidomimetics, etc. or mimicking natural products were much higher. This highlights the potential role of natural products in the further establishment of new antiviral agents [29]. The focus on the antiviral potential of compounds isolated from marine fungi came to light in 1998 after the isolation of stachyflin from Stachybotrys sp. RF-7260 by Taishi and colleagues; it had promising antiviral activity against influenza A virus (H1N1) [30]. Until 2006, a limited number of compounds with antiviral activity was reported, as reviewed by Bhadury and colleagues [3]. However, over the last decade, numerous compounds with promising antiviral activities against various viruses were isolated from marine fungi. Later in this review, we outline the types of viruses which were subjected to marine fungi-derived compounds and elucidate their source of isolation and antiviral potential (Figure 1, Table 1).

\subsection{Enterovirus-71 (EV-71)}

After the virtual eradication of poliovirus, enterovirus 71 (EV-71), a member of the Picornaviridae family, has emerged as a critical non-polio neurotropic enterovirus. EV71 provokes acute neurological disease in children, which may result in cardiopulmonary failure and death. However, this non-enveloped, positive $(+)$ strand RNA virus is a major cause of hand, foot, and mouth disease [31]. During the largest epidemic in Taiwan in 1998, more than 100,000 children were infected with EV-71 [32]. Despite extensive research from compound library screening to target-based chemical design, pharmaceutical developments have failed to meet pharmacological expectations [33].

The antiviral activity of three compounds, stachybogrisephenone B (1), grisephenone A (2), and 3,6,8-Trihydroxy-1-methylxanthone (3), which are new sesquiterpenoid and xanthone derivatives isolated from the cultures of sponge-derived fungus Stachybotry sp. HH1 ZDDS1F1-2, have been evaluated against in vitro replication of EV-71. The so-called compounds showed inhibitory activities against in vitro replication of EV71 with IC50 values of 30.1, 50.0 and $40.3 \mu \mathrm{M}$ [34]. The efficiency of these cytotoxic compounds identified them as potential candidates for further studies towards drug discovery for EV-71 and other related viruses such as Coxsackie virus [35]. 
<smiles>COc1cc(O)c(C(=O)c2c(O)cc(OC)c(Cl)c2O)c(O)c1</smiles>

1<smiles>COc1cc(OC)c(C(=O)c2c(I)cc(O)cc2OC)c(O)c1Cl</smiles>

2<smiles>Cc1cc(O)cc2oc3cc(O)cc(O)c3c(=O)c12</smiles>

3<smiles>[R]C([R7])[C@H](NC(=O)[C@H](CC(C)C)NC(=O)[C@@H]1CN(C(=O)C(C)(C)NC(=O)[Y6](C)C)C[C@H]1[R2])C(=O)N[C@@H](CCC(N)=O)C(=O)N[C@@H](CO)CC(C)C</smiles>

$4 \mathrm{R}_{1}=\mathrm{CH}_{3}, \mathrm{R}_{2}=\mathrm{OH}, \mathrm{n}=12$

$5 \mathrm{R}_{1}=\mathrm{H}, \mathrm{R}_{2}=\mathrm{OH}, \mathrm{n}=12$

$6 \mathrm{R}_{1}=\mathrm{CH}_{3}, \mathrm{R}_{2}=\mathrm{H}, \mathrm{n}=12$

$7 \mathrm{R}_{1}=\mathrm{CH}_{3}, \mathrm{R}_{2}=\mathrm{OH}, \mathrm{n}=10$

$8 \mathrm{R}_{1}=\mathrm{CH}_{3}, \mathrm{R}_{2}=\mathrm{H}, \mathrm{n}=10$

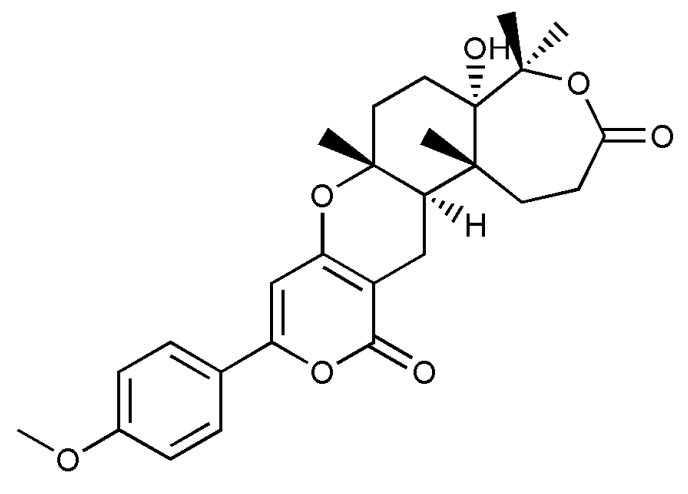

9<smiles>COC1=CC2=CC(=C3c4cc2oc(=O)c4C[C@@]3(O)[C@@]2(C)CC[C@@]3(O)C(C)(C)C=CC(=O)[C@@]3(C)O2)OC1(O)O</smiles>

10<smiles>COC1(Cc2ccc(O)cc2)OC(=O)C(O)=C1c1ccc(O)cc1</smiles>

11<smiles>C[C@@H]1Cc2cc(C[C@@]3(OC(=O)[O-])OC(=O)C(O)=C3c3ccc(O)cc3)ccc2OC1(C)C</smiles>

12

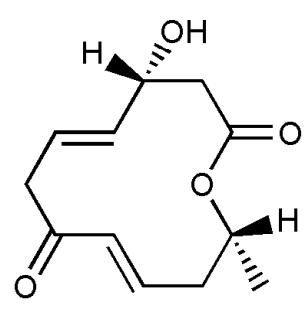

13

Figure 1. Cont. 
<smiles>O=C1O/C(=C(/C(=O)O)c2ccccc2)C(O)=C1c1ccccc1</smiles>

32<smiles>CCC[C@]1(OC)OC(=O)c2c1cc(O)c(O)c2C</smiles>

37<smiles>[R]c1c(OC)cc2c(c1[R])CNC2=O</smiles>

$33 \mathrm{R}_{1}=\mathrm{OH}, \mathrm{R}_{2}=\mathrm{OCH}_{3} \quad \mathrm{HO}_{\mathrm{OH}}$ $34 \mathrm{R}_{1}=\mathrm{OCH}_{3}, \mathrm{R}_{2}=\mathrm{OH}$<smiles>O=Cc1cc(C(=O)O)cc(O)c1C(=O)c1c(O)cccc1O</smiles>

38<smiles>C/C=C/C=C/C(O)=C1/C(=O)C2(C)C(=O)C(C)(O)C1CC(c1ccc(O)c(OC)c1)C2C</smiles><smiles>COc1cc(O)c2c(c1)C(=O)c1cc(C)c(O)c(-c3c(O)cc4c(c3O)C(=O)c3cc(O)c(C)cc3C4=O)c1C2=O</smiles>
$35 \mathrm{R}_{1}=\mathrm{OH}, \mathrm{R}_{2}=\mathrm{OH}$<smiles>[R]c1c(O)cc(O)c(C(=O)O[C@]2(C)C(=O)C=C3C=C(/C=C/C)OC([R2])[C@@]3(O)C2=O)c1C</smiles>

$$
\mathrm{H} \quad 36 \mathrm{R}_{1}=\mathrm{H}, \mathrm{R}_{2}=\mathrm{H}
$$


<smiles>CN[C@@H](C(=O)O[C@H]1CC[C@](C)(/C=C/c2ccc3c(c2O)[C@@](O)(c2ccccc2)[C@H](OC)C(=O)N3)C[C@@H]1C)C(C)C</smiles><smiles>O=c1[nH]c(Cc2ccc(O)cc2)nc2ccccc12</smiles>

\section{5}<smiles>O=C(c1ccc(O)cc1)c1nc2ccccc2c(=O)[nH]1</smiles><smiles>COC(=O)Cc1ccc(O)cc1</smiles>

47<smiles>COC(=O)C1c2c(oc3cc(CO)cc(O)c3c2=O)C=CC1O</smiles>

46

48<smiles>O=C(O)c1ccc(O)c(O)c1</smiles>

49

Figure 1. Chemical structures of marine fungi-derived compounds with antiviral activity.

Table 1. Antiviral activities of marine fungi and their mechanism of action.

\begin{tabular}{|c|c|c|c|c|c|}
\hline Virus & Antiviral Agent & Source & Chemical Class & Effect/Mechanism & Reference \\
\hline \multirow{3}{*}{ EV71 } & Stachybogrisephenone B (1) & Stachybotrys sp. & Xanthone & $\mathrm{IC}_{50}: 30.1 \mu \mathrm{M}$ & [34] \\
\hline & Grisephenone A (2) & Stachybotrys sp & Xanthone & $\mathrm{IC}_{50}: 50.0 \mu \mathrm{M}$ & [34] \\
\hline & 3,6,8-Trihydroxy-1-methylxanthone (3) & Stachybotrys sp & Xanthone & $\mathrm{IC}_{50}: 40.3 \mu \mathrm{M}$ & [34] \\
\hline \multirow{6}{*}{ HSV } & Halovirs A-E (4-8) & Scytalidium sp. & Peptide & direct inactivation & [36] \\
\hline & 11a-dehydroxyisoterreulactone A (9) & $\begin{array}{c}\text { Aspergillus terreus } \\
\text { SCSGAF0162 }\end{array}$ & Lactone & $\mathrm{IC}_{50}: 33.38 \mu \mathrm{M}$ & [37] \\
\hline & Arisugacin A (10) & $\begin{array}{c}\text { Aspergillus terreus } \\
\text { SCSGAF0162 }\end{array}$ & Lactone & $\mathrm{IC}_{50}: 12.76 \mu \mathrm{M}$ & [37] \\
\hline & Isobutyrolactone II (11) & $\begin{array}{c}\text { Aspergillus terreus } \\
\text { SCSGAF0162 }\end{array}$ & Lactone & $\mathrm{IC}_{50}: 62.08 \mu \mathrm{M}$ & [37] \\
\hline & Aspernolide A (12) & $\begin{array}{c}\text { Aspergillus terreus } \\
\text { SCSGAF0162 }\end{array}$ & Lactone & $\mathrm{IC}_{50}: 68.16 \mu \mathrm{M}$ & [37] \\
\hline & Balticolid (13) & Ascomycetous strain 222 & Macrolide & $\mathrm{IC}_{50}: 0.45 \mu \mathrm{M}$ & [38] \\
\hline \multirow[b]{3}{*}{ HIV } & Equisetin (14) & Fusarium heterosporum & Tetramic acid & $\mathrm{IC}_{50}: 15 \mu \mathrm{M}$ & [39] \\
\hline & Phomasetin (15) & Phoma sp. & Tetramic acid & $\mathrm{IC}_{50}: 10 \mu \mathrm{M}$ & [39] \\
\hline & Integric acid (16) & Xylaria sp. & $\begin{array}{c}\text { Acylated } \\
\text { eremophilane } \\
\text { sesquiterpenoid }\end{array}$ & $\mathrm{IC}_{50}: 10 \mu \mathrm{M}$ & [40] \\
\hline
\end{tabular}


Table 1. Cont.

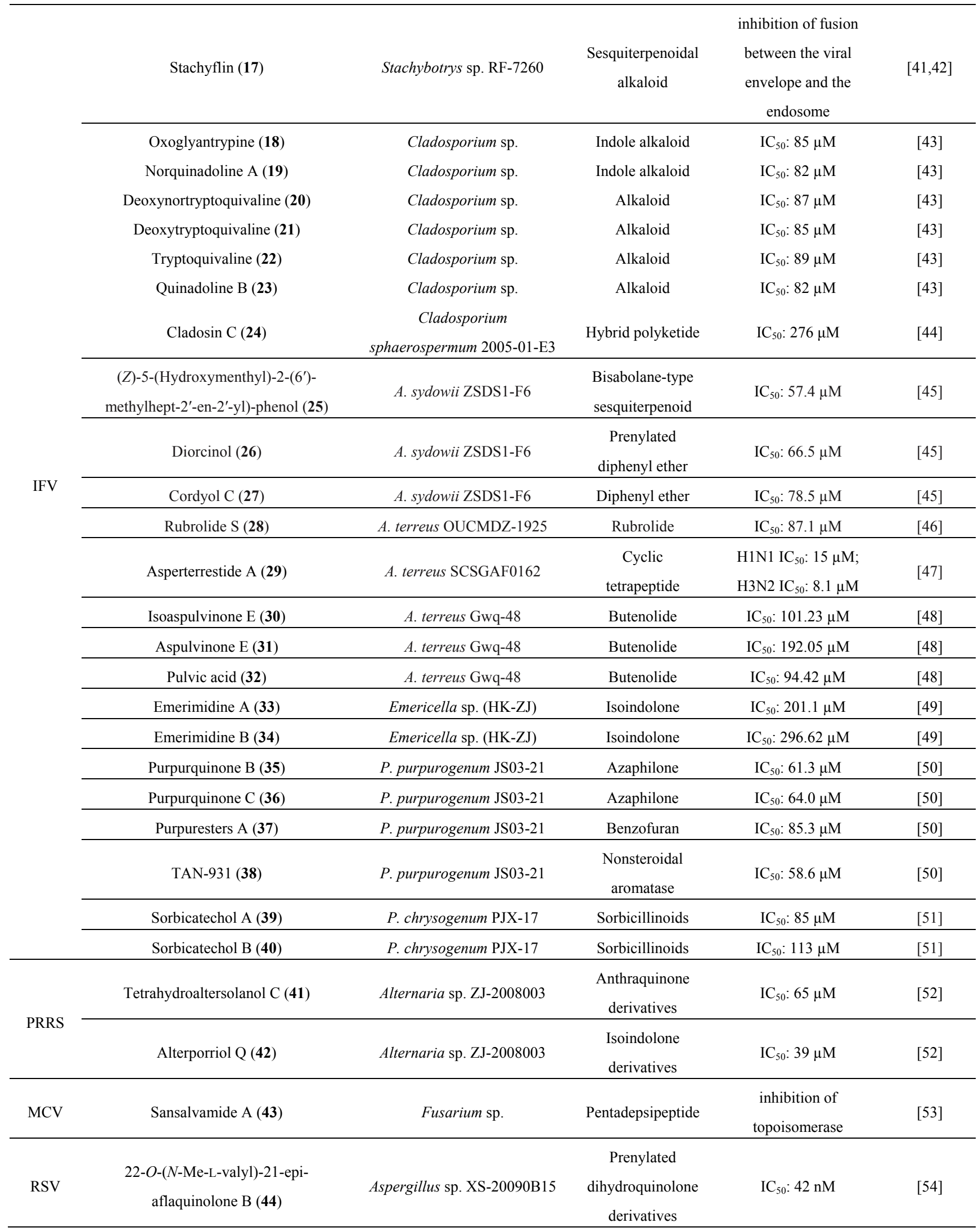


Table 1. Cont.

\begin{tabular}{|c|c|c|c|c|c|}
\hline \multirow{5}{*}{ TMV } & $\begin{array}{c}\text { 2-(4-hydroxybenzyl) quinazolin-4(3H)- } \\
\text { one (45) }\end{array}$ & P. oxalicum $0312 \mathrm{~F}_{1}$ & Alkaloid & $\mathrm{EC}_{50}: 399.57 \mu \mathrm{M}$ & {$[55,56]$} \\
\hline & $\begin{array}{l}\text { 2-(4-hydroxybenzoyl) quinazolin- } \\
\qquad 4(3 \mathrm{H}) \text {-one }(46)\end{array}$ & P. oxalicum $0312 \mathrm{~F}_{1}$ & Alkaloid & $\mathrm{EC}_{50}$ not tested & {$[55,56]$} \\
\hline & Methyl 4-hydroxyphenylacetate (47) & P. oxalicum $0312 \mathrm{~F}_{1}$ & Ester & $\mathrm{EC}_{50}: 829.15 \mu \mathrm{M}$ & {$[55,56]$} \\
\hline & AGI-B4 (48) & Neosartorya fischeri 1008F1 & $\begin{array}{c}\text { Dihydroxanthenon } \\
\mathrm{e} \\
\end{array}$ & $\mathrm{IC}_{50}: 260 \mu \mathrm{M}$ & {$[57]$} \\
\hline & 3,4-dihydroxybenzoic acid (49) & Neosartorya fischeri $1008 \mathrm{~F} 1$ & Polyphenol & $\mathrm{IC}_{50}: 630 \mu \mathrm{M}$ & {$[57]$} \\
\hline
\end{tabular}

\subsection{Herpes Simplex Viruses (HSVs)}

HSV-1 and HSV-2 are important and prevalent human pathogens from Herpesviridae family. These HSVs are characterized by four main constituents, namely an icosapentahedral capsid, an amorphous layer of proteins surrounding the capsid, an envelope, and an electron-dense core with large double-stranded DNA. HSV-1 is the main causative agent for orofacial infections such as cold sores, while HSV-2 is associated with a sexual transmitted infection (STI) - namely, genital herpes - that also can be transmitted to neonates during delivery through the infected mother's birth canal. Despite numerous reports of natural products with inhibitory effects against HSV, commercial drugs are generally limited to synthetic antiviral agents with a natural product pharmacophore such as acyclovir, penciclovir, and famciclovir [58,59].

Halovirs A-E (4-8), a series of lipophilic linear peptides that were isolated from the genus Scytalidium during saline fermentation [40], exhibited in vitro antiviral activity against HSV-1 and HSV-2 in a time- and dose-dependent manner. This activity was suggested to be through viral membrane destabilization. These fungal metabolites exert direct virucidal activity against extracellular HSV particles as an applicable approach to the inhibition of HSV transmission [36].

Nong and colleagues (2014) [37] reported the antiviral activity of four compounds including 11a-dehydroxyisoterreulactone A (9), arisugacin A (10), isobutyrolactone II (11), and aspernolide A (12), with $\mathrm{IC}_{50}$ values against $\mathrm{HSV}-1$ of $33.38,12.76,62.08$, and $68.16 \mu \mathrm{M}$, respectively. These compounds derived from a marine fungus, Aspergillus terreus SCSGAF0162, which was isolated from the South China Sea $\left(18^{\circ} 11^{\prime} \mathrm{N}, 109^{\circ} 25^{\prime} \mathrm{E}\right)$ gorgonian corals Echinogorgia aurantiaca, under solid-state fermentation of rice.

A new 12-membered macrolide, balticolid (13), is one of the antiviral naphthalenone byproducts from the ethyl acetate (EtOAc) extract of the culture broth of fungal strain 222 belonging to the Ascomycota, which was obtained on driftwood gathered from the Greifswalder Bodden shore, Baltic Sea, Germany. To evaluate the antiviral activity of balticolid against influenza A virus and HSV-I, the non-cytotoxic concentrations of the compound were examined on in vitro replication of both viruses. Balticolid showed potent inhibitory effects against HSV-I with $\mathrm{IC}_{50}=0.45 \mu \mathrm{M}$. However, there was no significant antiviral activity against in vitro replication of the influenza A virus [38]. 


\subsection{Human Immunodeficiency Virus (HIV)}

HIV causing acquired immunodeficiency syndrome (AIDS) is the major contributing factor for the elevation of infectious disease mortality all around the world [60]. This member of the Retroviridae family has a unique structure, which contains two copies of positive single-stranded RNA and a conical capsid. HIV has the potential to infect pivotal cells of the human immune system such as dendritic cells, macrophages, and mainly T helper cells. Until 2014, 28 antiretroviral drugs were on the market to treat HIV infection and classified based on their drug class into six main groups, integrase inhibitors, protease inhibitors, non-nucleoside reverse transcriptase inhibitors, nucleoside/nucleotide reverse transcriptase inhibitors, and entry inhibitors (fusion inhibitors and CCR5 agents) [61]. However, the annual expense of pharmaceutics for each individual can reach up to $\$ 24,000$ in the US, depending on the group of anti-HIV drugs $[62,63]$.

Equisetin (14) and its new enantiomeric homologue, phomasetin (15), isolated from the marine fungi Fusarium heterosporum and Phoma sp., respectively, exhibited in vitro inhibitory activity against the integrase enzyme of HIV-1, which is an important enzyme for the HIV-1 replication cycle. Further characterization of the active compound from a marine fungal species, Xylaria sp., yielded integric acid (16), which structurally is similar to equisetin (14) as a novel and unique class of integrase inhibitors [39]. These compounds prevent the amalgamation reactions catalyzed by pre-integration compounds derived from HIV-1-infected cells [24,64]. Integric acid impeded 3 end activity and strand transferal reactions, both with $\mathrm{IC}_{50}=10 \mu \mathrm{M}$.

\subsection{Influenza Virus}

Every few years, emergence of a novel influenza virus with fatal pathogenicity attracts global attention to the marked numbers of afflicted patients and the high rate of death; still human beings are confounded by virus recombination [65]. Reformulation of the annual vaccine based on the expected upcoming influenza strains is always accompanied by some failures due to unforeseen pandemic viruses and antigenic mismatch [66]. Influenza A virus, a member of the Orthomyxoviridae family, is a negative (-) strand RNA virus and has several subtypes named based on the $\mathrm{H}$ (hemagglutinin) and $\mathrm{N}$ (neuraminidase) antigens. Birds are the main host for influenza A virus; however, transmission to domestic poultry may infect some mammals and provoke dangerous human influenza pandemics [67]. Respiratory droplets, aerosols, and direct contact with secretions are mentioned as the three main modes for viral transmission [68].

Stachyflin (17) was isolated from Stachybotrys sp. RF-7260 by the solid-state fermentation method. This terpenoid elicited an $\mathrm{IC}_{50}=0.003 \mu \mathrm{M}$ against influenza A virus (H1N1), which was comparable with other antiviral agents such as zanamivir and amantadine [41]. It is suggested that stachyflin, with a unique mechanism of action, suppresses the first stage of $\mathrm{H} 1 \mathrm{~N} 1$ and $\mathrm{H} 2 \mathrm{~N} 2$ viral infections (entering into the host cell through fusion between the viral envelope and endosomal membrane) [42]. This antiviral activity was confirmed in an in vivo study by oral administration of stachyflin and its derivatives with a solution in PEG [42].

In light of investigations for discovering anti-influenza compounds, an effective mangrove-derived fungal strain, Cladosporium sp., has been identified with potential for further study. A chemical 
analysis of the EtOAc decoctions of both the fermentation broth and mycelia of the fungus, which led to the isolation of six novel byproducts of glyantrypine and pyrazinoquinazoline (indole alkaloids), with potential antiviral property against H1N1 strain of influenza virus. The resultant compounds, oxoglyantrypine (18), norquinadoline A (19), deoxynortryptoquivaline (20), deoxytryptoquivaline (21), tryptoquivaline (22), and quinadoline B (23) revealed noteworthy antiviral activities against H1N1 strain with $\mathrm{IC}_{50}$ values of $85,82,87,85,89$, and $82 \mu \mathrm{M}$, respectively [43]. In a later assay, Wu and colleagues (2014) [44] evaluated the secondary bioactive metabolites from a deep-sea-derived fungus, Cladosporium sphaerospermum 2005-01-E3, obtained from residues in the Pacific Ocean. The novel compound cladosin C (24) showed moderate antiviral activity against influenza A (H1N1) virus with an $\mathrm{IC}_{50}=276 \mu \mathrm{M}$.

In addition, a recent study identified new bioactive natural compounds from a sponge-associated fungi, the ZSDS1-F6 strain of Aspergillus sydowii, which was isolated from an unknown marine sponge gathered from the Xisha Islands of China. The derived compounds, (Z)-5-(Hydroxymenthyl)-2(6')-methylhept-2'-en-2'-yl)-phenol (25), diorcinol (26) and cordyol C (27), exhibited minor antiviral activity against the influenza (H3N2) virus with $\mathrm{IC}_{50}$ values of $57.4,66.5$, and $78.5 \mu \mathrm{M}$, respectively [45]. Furthermore, two novel rubrolide compounds were isolated from the fermentation stock of the marine-derived fungus Aspergillus terreus (OUCMDZ-1925 strain) by Zhu and colleagues [46] ,of which rubrolide $\mathrm{S}(\mathbf{2 8})$ presented prominent antiviral activity against influenza A (H1N1) virus with an $\mathrm{IC}_{50}=87.1 \mu \mathrm{M}$.

Asperterrestide A (29), a cyclic tetrapeptide compound with antiviral properties that derived from the fungal strain of $A$. terreus SCSGAF0162, was isolated from the tissue of the gorgonian Echinogorgia aurantiaca, collected from Sanya, Hainan Province, China. 29 displayed suppressive impacts on the influenza virus strains A/WSN/33 (H1N1) and A/Hong Kong/8/68 (H3N2) with IC50 values of 15 and $8.1 \mu \mathrm{M}$, respectively [47]. Further research was conducted on a new strain, A. terreus Gwq-48, which was derived from a mangrove rhizosphere soil sample in the coast of Fujian state. The analysis of its chemical ingredients resulted in the segregation of one novel aspulvinone, isoaspulvinone $\mathrm{E}$ (30), aspulvinone $\mathrm{E}$ (31), and pulvic acid (32), which exhibited notable anti-influenza A (H1N1) virus activities, with IC 50 values of 101.23, 192.05, and $94.42 \mu \mathrm{M}$, respectively [48].

An investigation with the goal of producing an anti-influenza virus resulted in the isolation of a fungus verified as Emericella sp. (HK-ZJ), isolated from the internal rind of a mangrove plant Aegiceras corniculatum in the district of HaiKou, China [49]. Following the evaluation of ten compounds, emerimidine A and B (33 \& 34), emeriphenolicins A and D, aspernidine A and B, austin, austinol, dehydroaustin, and acetoxydehydroaustin, for their in vitro effect against replication of $\mathrm{H} 1 \mathrm{~N} 1$ in MDCK cells, just two compounds, 33 and 34, displayed average suppressive effects with IC50 values of 201.1 and $296.62 \mu \mathrm{M}$, respectively.

A recent study on novel drugs against the influenza virus from extremophiles, an acid-tolerant fungal strain JS03-21, determined as Penicillium purpurogenum, was derived from the regional red soil by the Lujiang River from Jianshui, Yunnan, China. Subsequently, the antiviral activity was detected for compounds purpurquinones B and C (35 \& 36), purpuresters A (37), and TAN-931 (38) against H1N1, with IC50 values of $61.3,64.0,85.3$, and $58.6 \mu \mathrm{M}$, respectively [50]. In a further late study conducted by Peng and colleagues [51], on the same genus but a different strain called Penicillium chrysogenum PJX-17, two novel compounds, sorbicatechols A and B (39 \& 40), were properly isolated from a 
sorbicillin component and a styrene moiety by endo- and exo-Diels-Alder cycloadditions, and both of them showed anti-H1N1 activity, with IC50 values of 85 and $113 \mu \mathrm{M}$, respectively.

\subsection{Porcine Reproductive and Respiratory Syndrome Virus (PRRSV)}

PRRSV is a member of the Arteriviridae family with a complex epidemiological profile due to the persistence of the virus in tissue even several months after the acute stage. This small, enveloped, positive $(+)$ strand RNA virus infects pigs and causes respiratory illness and a major failure in the reproduction of sows. An RNA genome of about 15 kilobases in size is responsible for the coding of two principal polyproteins, namely 1a and 1ab [69]. PRRSV classifies into two subgroups, namely A and B, representing the North American and European strains, which have different level of virulence. Similar to the other viruses in this family, the PRRS virus targets macrophages [54]. Assorted methods of PRRSV transmission via different fomites such as equipment, hands, needles, and footwear associated with mechanical transmitters, including flies and mosquitoes, increase the high risk of PRRSV infection [70]. Despite the prevalence of vaccines, control of the virus infection in usual swine conditions has always been a major hindrance to food industries [54].

A recent investigation by Zheng and colleagues [52] reported two marine-derived compounds with antiviral potential against PRRSV. Tetrahydroaltersolanol C (41) and alterporriol Q (42) were isolated from the marine-derived fungus ZJ-2008003, obtained from Sarcophyton sp., a soft coral in the South China Sea. Molecular and morphological characterizations identified the isolated species as an Alternaria sp. The compounds $\mathbf{4 1}$ and $\mathbf{4 2}$ revealed antiviral activities against PRRSV with IC50 values of 65 and $39 \mu \mathrm{M}$, respectively [52].

\subsection{Molluscum Contagiosum Virus (MCV)}

As a member of the Poxviridae, MCV has a unique mode of replication in the human epidermis: itprecipitates a common skin infection, especially in children, through augmentation of epidermal cell mitosis and disruption of cell differentiation. However, similar to other species in this family, this linear, double-stranded DNA virus is characterized by lateral bodies, a core, an envelope, and a surface membrane. The viral genome and replication afflicts several cellular pathways, including cell death, cell cycle, inflammation, and innate immunity. To escape from immune surveillance, the MCV virus does not pass the basement membrane of the epidermis. MCV skin diseases can be comfortably recognized, and a combination of topical treatment and local physical therapy can efficaciously obliterate the virus infection [71].

Sansalvamide A (43), isolated from a marine fungus, Fusarium sp. [72] as a cyclic depsipeptide, elicited inhibitory activity against topoisomerase of MCV. The antiviral effect against this pathogen $\left(\mathrm{IC}_{50}=124 \mu \mathrm{M}\right)$ was induced through suppression of topoisomerase-mediated DNA-binding, DNA relaxation, and formation of covalent complex [53]. Due to close correlation between MCV lesions and AIDS patients, this antiviral activity was considered a noteworthy bioactivity for marine fungi [73]. Hence, development of cyclic depsipeptide derivatives from sansalvamide A may catalyze the discovery of new generations of anti-MCV agents. 


\subsection{Respiratory Syncytial Virus (RSV)}

As a member of the Paramyxoviridae family, RSV is responsible for the most abundant infection in the lower respiratory tract of young children and infants and causes approximately 100,000 pediatric infections with 250 deaths each year in the United States [74]. This negative (-) strand RNA virus with approximately 15 kilobases has 10 genes, which are responsible for the production of 11 viral proteins. The infection process is triggered through binding to host cell receptors by $\mathrm{G}$ protein. Following the attachment as a surface viral protein, F protein causes the combination of nearby cells and subsequent formation of "syncytia," which inspired the name of the virus [75]. There are only limited therapeutic agents such as palivizumab and ribavirin that are reported against RSV, and this fact illustrates the urgent need for the development of new anti-RSV drugs [74].

Screening of an extract isolated from Aspergillus sp. XS-20090B15, which has been derived from the gorgonian Muricella abnormaliz from the South China Sea and cultured on a rice medium, revealed anti-RSV activity. Compound 22-O-( $N$-Me-L-valyl)-21-epi-aflaquinolone B (44) exhibited exceptional anti-RSV activity with an $\mathrm{IC}_{50}$ value of $42 \mathrm{nM}$, roughly 500 times more potent than ribavirin, the positive control used in this study, with $\mathrm{IC}_{50}=20 \mu \mathrm{M}$ [54]. In addition, aflaquinolone $\mathrm{D}$, another compound of the same fungus, showed anti-RSV activity but not as potent as the former $\left(\mathrm{IC}_{50}=6.6 \mu \mathrm{M}\right)$.

\subsection{Tobacco Mosaic Virus (TMV)}

As a plant virus, TMV markedly debilitates the horticulture and agriculture industries [76]. This rod-like virus has a complex capsid and positive $(+)$ strand RNA with approximately 6.4 kilobases. TMV infection creates particular distinguishing features on plants, including leaf discoloration and mosaic mottling [77]. Infection of more than 400 assorted plant species from 36 families, including cucumber, potato, tomato, and tobacco, foregrounds the importance of TMV. However, after infection by a virus, there is no definite treatment for the TMV infections [78-80]. Due to the possible side effects of synthetic drugs on plants, natural product derivatives can be more compatible with infected hosts.

Recent surveys reported that the extract of strain $0312 \mathrm{~F}_{1}$ from Penicillium oxalicum exhibited a strong inhibitory activity against the replication of TMV $[55,56]$. Bioactivity analyses indicated that 2-(4-hydroxybenzyl) quinazolin-4(3H)-one (45) and methyl 4-hydroxyphenylacetate (47) possessed strong suppressive activity against TMV with $\mathrm{EC}_{50}$ values of $399.57 \mu \mathrm{M}$ and $829.15 \mu \mathrm{M}$, respectively; while, compared to those, the new compound 2-(4-hydroxybenzoyl) quinazolin-4(3H)-one (46) revealed average suppressive activity against TMV (EC50 was not tested) [49]. Prior to this study, Tan and colleagues (2012) [57] reported the antiphytoviral properties of marine-derived fungus Neosartorya fischeri strain 1008F1. The bioactive assays signifying those two compounds, AGI-B4 (48) and 3,4-dihydroxybenzoic acid (49), showed strong inhibitory impact on the replication of tobacco mosaic virus (TMV), with IC50 values of 260 and $630 \mu \mathrm{M}$, respectively.

\section{Conclusions}

The increasing rate of viral resistance to antiviral drugs and drug toxicity is becoming a challenging problem in antiviral therapy. There are numerous reports on the resistance of different viruses to 
approved antiviral drugs [81-83]. However, there are many viral infections without any available effective treatment. Therefore, natural products from different living organisms including marine organisms could be potential candidates for development of new antiviral drugs. As we summarized in this review, there are different biomolecules from different chemical categories containing peptides, alkaloids, terpenoids, diacyglycerols, steroids, polysaccharides, and even more from different marine fungi with significant antiviral activities, as shown especially through in vitro studies $[47,84,85]$. Therefore, further investigation towards in vivo and even pharmacological studies for some of the abovementioned effective compounds seems to be crucial.

Organisms inhabiting the marine environment provide a diversity of bioactive compounds, which are exclusive as the aqueous habitat demands molecules with particular and vigorous biological compounds. Many scholars are devoted to investigating marine organisms to determine the development of potential biomolecules into therapeutic drugs and numerous compounds from marine fungi have been shown to possess notable antiviral activities. On the other hand, there are many important animal and human viruses yet to be studied, since for most viral diseases there has not been any effective therapeutic treatment available thus far. Therefore, infectious viruses with widespread prevalence, including EV71, HSV, HIV, MCV, and RSV, were used to examine the antiviral potential of the isolated compounds. Moreover, viruses responsible for important plant and animal infections, namely TMV and PRRS, were also employed in several studies. All together, the results showed quite noticeable cytotoxic effects against the respective viruses. From the preceding statement, we presented various compounds isolated from different marine fungi genera of which the most important ones exploited for their antiviral potential were Aspergillus sp., Penicillium sp., Cladosporium sp., Stachybotrys sp., and Neosartorya sp.; they are summarized in Table 1. Among these compounds, 13, a newly derived strain of Ascomycete, revealed marked inhibitory activity against HSV. Furthermore, 17 prompted a potent anti-influenza virus activity by showing a very low $\mathrm{IC}_{50}$ value $(0.003 \mu \mathrm{M})$ and also oral administration of $\mathbf{1 7}$ in an in vivo study in PEG confirmed its significant antiviral activity. Furthermore, 44 exhibited a notable potency to elicit substantial antiviral activity against RSV. Nonetheless, the majority of the investigations were limited to basic screening and no mechanism of action was established for active compounds. It is pivotal for further research to characterize and determine the virus or host factors, which were targeted by antiviral compounds.

To develop antiviral drugs derived from marine fungi, in vivo and clinical studies are other aspects that should be exploited. The variety of the natural products from marine fungi evidently determines the potential for assigning some selected compounds to in vivo and probably clinical trials for forthcoming progress of anti-infective drugs. One of the considerable upcoming challenges will be the extensive production of these compounds to meet the demand for clinical trials and drug development. Several investigators believe that a specific form of combined genetic and metabolic engineering will be the potential resolution for commercial manufacture of these compounds [3]. It is hoped that this review could be a helpful source of guidance towards the discovery of new antiviral drugs. 


\section{Acknowledgments}

The authors would like to thank the Ministry of Higher Education (MOHE), Malaysia, for High Impact Research (HIR) MOHE Grant (E000013-20001) and Long-Range Grant Scheme (LRGS) LR001/2011F. We also would like to thank University Malaya for UMRG fund (RG356-15AFR).

\section{Conflicts of Interest}

The authors declare no conflict of interest.

\section{References}

1. Vo, T.-S.; Kim, S.-K. Potential anti-HIV agents from marine resources: An overview. Mar. Drugs 2010, 8, 2871-2892.

2. Aneiros, A.; Garateix, A. Bioactive peptides from marine sources: Pharmacological properties and isolation procedures. J. Chromatogr. B 2004, 803, 41-53.

3. Bhadury, P.; Mohammad, B.T.; Wright, P.C. The current status of natural products from marine fungi and their potential as anti-infective agents. J. Ind. Microbiol. Biotechnol. 2006, 33, 325-337.

4. Simon, C.; Daniel, R. Metagenomic analyses: Past and future trends. Appl. Environ. Microbiol. 2011, 77, 1153-1161.

5. Faulkner, D.J. Marine pharmacology. Antonie Leeuwenhoek 2000, 77, 135-145.

6. Zorofchian Moghadamtousi, S.; Karimian, H.; Khanabdali, R.; Razavi, M.; Firoozinia, M.; Zandi, K.; Abdul Kadir, H. Anticancer and antitumor potential of fucoidan and fucoxanthin, two main metabolites isolated from brown algae. Sci. World J. 2014, 2014, doi:10.1155/2014/768323.

7. Faulkner, D.J. Marine natural products. Nat. Prod. Rep. 2001, 18, 1R-49R.

8. Fenical, W. New pharmaceuticals from marine organisms. Trends Biotechnol. 1997, 15, 339-341.

9. König, G.M.; Wright, A.D.; Sticher, O.; Angerhofer, C.K.; Pezzuto, J.M. Biological activities of selected marine natural products. Planta Med. 1994, 60, 532-537.

10. Bugni, T.S.; Ireland, C.M. Marine-derived fungi: A chemically and biologically diverse group of microorganisms. Nat. Prod. Rep. 2004, 21, 143-163.

11. Kornprobst, J.-M.; Ha, T.B.T. Encyclopedia of Marine Natural Products; Wiley-Blackwell: Weinheim, Germany, 2010; Volume 1.

12. Hart, C. Forged in St. Anthony's fire: Drugs for migraine. Mod. Drug Disc. 1999, 2, 20-21.

13. Tresner, H.; Hayes, J.A. Sodium chloride tolerance of terrestrial fungi. Appl. Microbiol. 1971, 22, 210-213.

14. Smith, G.W.; Ives, L.D.; Nagelkerken, I.A.; Ritchie, K.B. Caribbean sea-fan mortalities. Nature 1996, 383, 487.

15. Alderman, D.; Polglase, J. Are fungal diseases significant in the marine environment? In The Biology of Marine Fungi; Cambridge University Press: Cambridge, UK, 1986; p. 189.

16. Porter, D. Mycoses of marine organisms: An overview of pathogenic fungi. In The Biology of Marine Fungi; Cambridge University Press: Cambridge, UK, 1986; p. 141.

17. Duarte, K.; Rocha-Santos, T.A.; Freitas, A.C.; Duarte, A.C. Analytical techniques for discovery of bioactive compounds from marine fungi. Trends Analyt. Chem. 2012, 34, 97-110. 
18. Kohlmeyer, J.; Kohlmeyer, E. Marine Mycology: The Higher Fungi; Academic Press: New York, NY, USA, 1979.

19. Blunt, J.W.; Copp, B.R.; Keyzers, R.A.; Munro, M.H.; Prinsep, M.R. Marine natural products. Nat. Prod. Rep. 2014, 31, 160-258.

20. Gallo, M.L.; Seldes, A.M.; Cabrera, G.M. Antibiotic long-chain and $\alpha, \beta$-unsaturated aldehydes from the culture of the marine fungus Cladosporium sp. Biochem. Syst. Ecol. 2004, 32, 545-551.

21. Abdel-Lateff, A.; Klemke, C.; König, G.M.; Wright, A.D. Two new xanthone derivatives from the algicolous marine fungus wardomyces anomalus. J. Nat. Prod. 2003, 66, 706-708.

22. Daferner, M.; Anke, T.; Sterner, O. Zopfiellamides A and B, antimicrobial pyrrolidinone derivatives from the marine fungus Zopfiella latipes. Tetrahedron 2002, 58, 7781-7784.

23. Gautschi, J.T.; Amagata, T.; Amagata, A.; Valeriote, F.A.; Mooberry, S.L.; Crews, P. Expanding the strategies in natural product studies of marine-derived fungi: A chemical investigation of Penicillium obtained from deep water sediment. J. Nat. Prod. 2004, 67, 362-367.

24. Tziveleka, L.-A.; Vagias, C.; Roussis, V. Natural products with anti-HIV activity from marine organisms. Curr. Top. Med. Chem. 2003, 3, 1512-1535.

25. Lou, Z.; Sun, Y.; Rao, Z. Current progress in antiviral strategies. Trends Pharmacol. Sci. 2014, $35,86-102$.

26. Tantillo, C.; Ding, J.; Jacobo-Molina, A.; Nanni, R.G.; Boyer, P.L.; Hughes, S.H.; Pauwels, R.; Andries, K.; Janssen, P.A.; Arnold, E. Locations of anti-aids drug binding sites and resistance mutations in the three-dimensional structure of HIV-1 reverse transcriptase: Implications for mechanisms of drug inhibition and resistance. J. Mol. Biol. 1994, 243, 369-387.

27. Morfin, F.; Thouvenot, D. Herpes simplex virus resistance to antiviral drugs. J. Clin. Virol. 2003, 26, 29-37.

28. Gilbert, C.; Boivin, G. Human cytomegalovirus resistance to antiviral drugs. Antimicrob. Agents Chemother. 2005, 49, 873-883.

29. Newman, D.J.; Cragg, G.M. Natural products as sources of new drugs over the 30 years from 1981 to 2010. J. Nat. Prod. 2012, 75, 311-335.

30. Taishi, T.; Takechi, S.; Mori, S. First total synthesis of ( \pm )-stachyflin. Tetrahedron Lett. 1998, 39, 4347-4350.

31. McMinn, P.; Stratov, I.; Nagarajan, L.; Davis, S. Neurological manifestations of Enterovirus 71 infection in children during an outbreak of hand, foot, and mouth disease in Western Australia. Clin. Infect. Dis. 2001, 32, 236-242.

32. Lin, T.-Y.; Chang, L.-Y.; Hsia, S.-H.; Huang, Y.-C.; Chiu, C.-H.; Hsueh, C.; Shih, S.-R.; Liu, C.-C.; Wu, M.-H. The 1998 Enterovirus 71 outbreak in Taiwan: Pathogenesis and management. Clin. Infect. Dis. 2002, 34, S52-S57.

33. Wu, K.X.; Ng, M.M.-L.; Chu, J.J. Developments towards antiviral therapies against Enterovirus 71. Drug. Discov. Today 2010, 15, 1041-1051.

34. Qin, C.; Lin, X.; Lu, X.; Wan, J.; Zhou, X.; Liao, S.; Tu, Z.; Xu, S.; Liu, Y. Sesquiterpenoids and xanthones derivatives produced by sponge-derived fungus Stachybotry sp. HH1 ZSDS1F1-2. J. Antibiot. 2014, 68, 121-125.

35. Rabenau, H.F.; Richter, M.; Doerr, H.W. Hand, foot and mouth disease: Seroprevalence of Coxsackie A16 and Enterovirus 71 in Germany. Med. Microbiol. Immun. 2010, 199, 45-51. 
36. Rowley, D.C.; Kelly, S.; Kauffman, C.A.; Jensen, P.R.; Fenical, W. Halovirs A-E, new antiviral agents from a marine-derived fungus of the genus Scytalidium. Bioorgan. Med. Chem. 2003, 11, 4263-4274.

37. Nong, X.-H.; Wang, Y.-F.; Zhang, X.-Y.; Zhou, M.-P.; Xu, X.-Y.; Qi, S.-H. Territrem and butyrolactone derivatives from a marine-derived fungus Aspergillus terreus. Mar. Drugs 2014, 12, 6113-6124.

38. Shushni, M.A.; Singh, R.; Mentel, R.; Lindequist, U. Balticolid: A new 12-membered macrolide with antiviral activity from an Ascomycetous fungus of marine origin. Mar. Drugs 2011, 9, 844-851.

39. Singh, S.B.; Zink, D.; Polishook, J.; Valentino, D.; Shafiee, A.; Silverman, K.; Felock, P.; Teran, A.; Vilella, D.; Hazuda, D.J. Structure and absolute stereochemistry of HIV-1 integrase inhibitor integric acid. A novel eremophilane sesquiterpenoid produced by a Xylaria sp. Tetrahedron Lett. 1999, 40, 8775-8779.

40. Rowley, D.C.; Kelly, S.; Jensen, P.; Fenical, W. Synthesis and structure-activity relationships of the halovirs, antiviral natural products from a marine-derived fungus. Bioorgan. Med. Chem. 2004, 12, 4929-4936.

41. Minagawa, K.; Kouzuki, S.; Yoshimoto, J.; Kawamura, Y.; Tani, H.; Iwata, T.; Terui, Y.; Nakai, H.; Yagi, S.; Hattori, N. Stachyflin and acetylstachyflin, novel anti-influenza a virus substances, produced by Stachybotrys sp. RF-7260. I. Isolation, structure elucidation and biological activities. J. Antibiot. 2002, 55, 155-164.

42. Yagi, S.; Ono, J.; Yoshimoto, J.; Sugita, K.-I.; Hattori, N.; Fujioka, T.; Fujiwara, T.; Sugimoto, H.; Hirano, K.; Hashimoto, N. Development of anti-influenza virus drugs I: Improvement of oral absorption and in vivo anti-influenza activity of stachyflin and its derivatives. Pharmaceut. Res. 1999, 16, 1041-1046.

43. Peng, J.; Lin, T.; Wang, W.; Xin, Z.; Zhu, T.; Gu, Q.; Li, D. Antiviral alkaloids produced by the mangrove-derived fungus Cladosporium sp. PJX-41. J. Nat. Prod. 2013, 76, 1133-1140.

44. Wu, G.; Sun, X.; Yu, G.; Wang, W.; Zhu, T.; Gu, Q.; Li, D. Cladosins A-E, hybrid polyketides from a deep-sea-derived fungus, Cladosporium sphaerospermum. J. Nat. Prod. 2014, 77, 270-275.

45. Wang, J.-F.; Lin, X.-P.; Qin, C.; Liao, S.-R.; Wan, J.-T.; Zhang, T.-Y.; Liu, J.; Fredimoses, M.; Chen, H.; Yang, B. Antimicrobial and antiviral sesquiterpenoids from sponge-associated fungus, Aspergillus sydowii ZSDS1-F6. J. Antibiot. 2014, 67, 581-583.

46. Zhu, T.; Chen, Z.; Liu, P.; Wang, Y.; Xin, Z.; Zhu, W. New rubrolides from the marine-derived fungus Aspergillus terreus OUCMDZ-1925. J. Antibiot. 2014, 67, 315-318.

47. He, F.; Bao, J.; Zhang, X.-Y.; Tu, Z.-C.; Shi, Y.-M.; Qi, S.-H. Asperterrestide A, a cytotoxic cyclic tetrapeptide from the marine-derived fungus Aspergillus terreus SCSGAF0162. J. Nat. Prod. 2013, 76, 1182-1186.

48. Gao, H.; Guo, W.; Wang, Q.; Zhang, L.; Zhu, M.; Zhu, T.; Gu, Q.; Wang, W.; Li, D. Aspulvinones from a mangrove rhizosphere soil-derived fungus Aspergillus terreus GWQ-48 with anti-influenza a viral (H1N1) activity. Bioorg. Med. Chem. Lett. 2013, 23, 1776-1778.

49. Zhang, G.; Sun, S.; Zhu, T.; Lin, Z.; Gu, J.; Li, D.; Gu, Q. Antiviral isoindolone derivatives from an endophytic fungus Emericella sp. Associated with Aegiceras corniculatum. Phytochemistry 2011, 72, 1436-1442. 
50. Wang, H.; Wang, Y.; Wang, W.; Fu, P.; Liu, P.; Zhu, W. Anti-influenza virus polyketides from the acid-tolerant fungus Penicillium purpurogenum JS03-21. J. Nat. Prod. 2011, 74, 2014-2018.

51. Peng, J.; Zhang, X.; Du, L.; Wang, W.; Zhu, T.; Gu, Q.; Li, D. Sorbicatechols A and B, antiviral sorbicillinoids from the marine-derived fungus Penicillium chrysogenum PJX-17. J. Nat. Prod. 2014, 77, 424-428.

52. Zheng, C.-J.; Shao, C.-L.; Guo, Z.-Y.; Chen, J.-F.; Deng, D.-S.; Yang, K.-L.; Chen, Y.-Y.; Fu, X.-M.; She, Z.-G.; Lin, Y.-C. Bioactive hydroanthraquinones and anthraquinone dimers from a soft coral-derived Alternaria sp. Fungus. J. Nat. Prod. 2012, 75, 189-197.

53. Hwang, Y.; Rowley, D.; Rhodes, D.; Gertsch, J.; Fenical, W.; Bushman, F. Mechanism of inhibition of a poxvirus topoisomerase by the marine natural product sansalvamide A. Mol. Pharmacol. 1999, 55, 1049-1053.

54. Prieto, C.; Castro, J.M. Porcine reproductive and respiratory syndrome virus infection in the boar: A review. Theriogenology 2005, 63, 1-16.

55. Shen, S.; Li, W.; Wang, J. A novel and other bioactive secondary metabolites from a marine fungus Penicillium oxalicum 0312f1. Nat. Prod. Res. 2013, 27, 2286-2291.

56. Shen, S.; Li, W.; Ouyang, M.A.; Wu, Z.; Lin, Q.; Xie, L. Identification of two marine fungi and evaluation of their antivirus and antitumor activities. Acta Microbiol. Sinic. 2009, 49, 1240-1246.

57. Tan, Q.-W.; Ouyang, M.-A.; Shen, S.; Li, W. Bioactive metabolites from a marine-derived strain of the fungus Neosartorya fischeri. Nat. Prod. Res. 2012, 26, 1402-1407.

58. Whitley, R.J.; Roizman, B. Herpes simplex virus infections. Lancet 2001, 357, 1513-1518.

59. Taylor, R.; Manandhar, N.; Hudson, J.; Towers, G. Antiviral activities of nepalese medicinal plants. J. Ethnopharmacol. 1996, 52, 157-163.

60. Armstrong, G.L.; Conn, L.A.; Pinner, R.W. Trends in infectious disease mortality in the United States during the 20th century. J. Am. Med. Assoc. 1999, 281, 61-66.

61. Kanters, S.; Mills, E.; Thorlund, K.; Bucher, H.; Ioannidis, J. Antiretroviral therapy for initial human immunodeficiency virus/AIDS treatment: Critical appraisal of the evidence from over 100 randomized trials and 400 systematic reviews and meta-analyses. Clin. Microbiol. Infect. 2014, 20, 114-122.

62. El-Sadr, W.M.; Holmes, C.B.; Mugyenyi, P.; Thirumurthy, H.; Ellerbrock, T.; Ferris, R.; Sanne, I.; Asiimwe, A.; Hirnschall, G.; Nkambule, R.N. Scale-up of HIV treatment through pepfar: A historic public health achievement. J. Acquir. Immune Defic. Syndr. 2012, 60, S96-S104.

63. Holmes, C.B.; Blandford, J.M.; Sangrujee, N.; Stewart, S.R.; DuBois, A.; Smith, T.R.; Martin, J.C.; Gavaghan, A.; Ryan, C.A.; Goosby, E.P. Pepfar's past and future efforts to cut costs, improve efficiency, and increase the impact of global HIV programs. Health Affairs 2012, 31, 1553-1560.

64. Hazuda, D.; Blau, C.U.; Felock, P.; Hastings, J.; Pramanik, B.; Wolfe, A.; Bushman, F.; Farnet, C.; Goetz, M.; Williams, M. Isolation and characterization of novel human immunodeficiency virus integrase inhibitors from fungal metabolites. Antivir. Chem. Chemother. 1999, 10, 63-70.

65. Gao, H.-N.; Lu, H.-Z.; Cao, B.; Du, B.; Shang, H.; Gan, J.-H.; Lu, S.-H.; Yang, Y.-D.; Fang, Q.; Shen, Y.-Z. Clinical findings in 111 cases of influenza a (H7N9) virus infection. N. Engl. J. Med. 2013, 368, 2277-2285.

66. Pica, N.; Palese, P. Toward a universal influenza virus vaccine: Prospects and challenges. Annu. Rev. Med. 2013, 64, 189-202. 
67. Scalera, N.M.; Mossad, S.B. The first pandemic of the 21st century: A review of the 2009 pandemic variant influenza a (H1N1) virus. Postgrad. Med. 2009, 121, 43-47.

68. Tellier, R. Review of aerosol transmission of influenza a virus. Emerg. Infect. Dis. 2006, 12, 1657-1662.

69. Lee, C.; Yoo, D. Cysteine residues of the porcine reproductive and respiratory syndrome virus small envelope protein are non-essential for virus infectivity. J. Gen. Virol. 2005, 86, 3091-3096.

70. Kristensen, C.; Bøtner, A.; Takai, H.; Nielsen, J.P.; Jorsal, S. Experimental airborne transmission of PRRS virus. Vet. Microbiol. 2004, 99, 197-202.

71. Chen, X.; Anstey, A.V.; Bugert, J.J. Molluscum contagiosum virus infection. Lancet Infect. Dis. 2013, 13, 877-888.

72. Heiferman, M.J.; Salabat, M.R.; Ujiki, M.B.; Strouch, M.J.; Cheon, E.C.; Silverman, R.B.; Bentrem, D.J. Sansalvamide induces pancreatic cancer growth arrest through changes in the cell cycle. Anticancer Res. 2010, 30, 73-78.

73. Thompson, C.H.; de Zwart-Steffe, R.T.; Donovan, B. Clinical and molecular aspects of Molluscum contagiosum infection in HIV-1 positive patients. Int. J. STD AIDS 1992, 3, 101-106.

74. Falsey, A.R.; Walsh, E.E. Respiratory syncytial virus infection in adults. Clin. Microbiol. Rev. 2000, 13, 371-384.

75. Feldman, S.A.; Hendry, R.M.; Beeler, J.A. Identification of a linear heparin binding domain for human respiratory syncytial virus attachment glycoprotein G. J. Virol. 1999, 73, 6610-6617.

76. Bos, L. Crop losses caused by viruses. Crop Prot. 1982, 1, 263-282.

77. Klug, A. The tobacco mosaic virus particle: Structure and assembly. Philos. Trans. R. Soc. Lond. B. Biol. Sci. 1999, 354, 531-535.

78. Creager, A.N.; Scholthof, K.-B.G.; Citovsky, V.; Scholthof, H.B. Tobacco mosaic virus: Pioneering research for a century. Plant Cell Online 1999, 11, 301-308.

79. Ritzenthaler, C. Resistance to plant viruses: Old issue, news answers? Curr. Opin. Biotechnol. 2005, 16, 118-122.

80. Yan, X.-H.; Chen, J.; Di, Y.-T.; Fang, X.; Dong, J.-H.; Sang, P.; Wang, Y.-H.; He, H.-P.; Zhang, Z.-K.; Hao, X.-J. Anti-tobacco mosaic virus (TMV) quassinoids from Brucea javanica (1.) Merr. J. Agric. Food. Chem. 2010, 58, 1572-1577.

81. Megens, S.; Laethem, K.V. Antiretroviral therapy and drug resistance in human immunodeficiency virus type 2 infection. Expert. Rev. Anti. Infect. Ther. 2013, 11, 1159-1178.

82. Menéndez-Arias, L.; Álvarez, M. Antiretroviral therapy and drug resistance in human immunodeficiency virus type 2 infection. Antiviral Res. 2014, 102, 70-86.

83. Komatsu, T.E.; Pikis, A.; Naeger, L.K.; Harrington, P.R. Resistance of human cytomegalovirus to ganciclovir/valganciclovir: A comprehensive review of putative resistance pathways. Antiviral Res. 2014, 101, 12-25.

84. Fan, Y.; Wang, Y.; Liu, P.; Fu, P.; Zhu, T.; Wang, W.; Zhu, W. Indole-diterpenoids with anti-H1N1 activity from the aciduric fungus Penicillium camemberti OUCMDZ-1492. J. Nat. Prod. 2013, $76,1328-1336$. 
85. Gong, K.-K.; Tang, X.-L.; Zhang, G.; Cheng, C.-L.; Zhang, X.-W.; Li, P.-L.; Li, G.-Q. Polyhydroxylated steroids from the south China sea soft coral Sarcophyton sp. And their cytotoxic and antiviral activities. Mar. Drugs 2013, 11, 4788-4798.

(C) 2015 by the authors; licensee MDPI, Basel, Switzerland. This article is an open access article distributed under the terms and conditions of the Creative Commons Attribution license (http://creativecommons.org/licenses/by/4.0/). 